continental area by the Cambrian marine transgression. Their ancestors are thus to be looked for beneath the existing oceans. The fossils now known from the American Algonkian may have been of fresh or brackish water types; littoral forms were occasionally imported among them from the series continuously developing in the seas. Walcott's studies of the Cambrian faunas of China are continued, with illustrations of new species of trilobites (vol. Ivii., No. 4). Evidence is given (ibid., No. 3) that certain medusiform fossils from the Middle Cambrian of British Columbia are in reality holothurians, being characterised by a large spiral alimentary canal. The descriptions and illustrations of these forms possess great interest for ail workers among Older Palæozoic strata.

G. A. J. C.

\section{STEREOSCOPIC VISION AND INSTRUMENTS.}

$W E$ have received a copy of a brochure entitled " Stereoskopisches Sehen und Messen" (pp. 40, price I mark), by Carl Pulfrich. This is the German version, or rather original, of the article "Stereoscope" in the recent new edition of the "Encyclopædia Britannica." A little more detail is given here and there in the German pamphlet than in the "Encyclopædia" article, and the former concludes with a very useful bibliography of papers published in the present century relating to binocular vision, which is not given in the "Encyclopædia." This is to be taken as supplementary to the bibliography in von Rohr's wellknown work "Die binokularen Instrumente" (see Supplement to Nature, March 5, rgo8) of memoirs published up to 1900 .

The pamphlet gives a concise, but clear and interesting, account of the more important points in the theory of stereoscopic vision; but its main value lies in the brief description which follows of the important modern developments and applications of stereoscopic methods, to which the author has himself so largely contributed. Not the least interesting among these are the well-known stereocomparator and the so-called "blink" microscope, the latter of which has proved so valuable in the detection of new planets and variable stars. We think it is desirable that attention should be drawn to the very imperfect, not to say unintelligible, translation of Pulfrich's text which constitutes the article in the "Encyclopædia Britannica" above referred to. It is surprising that both translator and editor should have allowed passages to pass which are so far astray from the original. Thus we read: "The reason for this [double images] is that when $\mathrm{P}$ (or $\mathrm{H}^{\prime}$ ) is fixed, the images of $\mathrm{H}^{\prime}$ (or P) are always separated from one another by the centre of the yellow spot." Fixed should be "focussed" (no doubt "fixiert," but the original is here paraphrased). Again: "The power of perception of depth in man is most accurate. This has been ascertained by the approximately equal keenness of vision of all normalsighted people and by the interpupillary distance." This is quite incomprehensible until one learns that the words in italics (ours) are a perversion of " Es wird bestimmt." "Parallax" (Parallaxe) appears as " parallel axis."

It is impossible briefly to convey an idea of the confusion in the mind of the reader caused by numerous errors of this description; but we would strongly recommend all those interested in the subject-matter of the article to refer to Pulfrich's German memoir.

\section{THE TECHNICAL COLLEGE, BRADFORD.}

$A \mathrm{~N}$ important extension of the buildings of the Bradford Technical College was opened by Lord Rotherham on October 25. The extension takes the form of a model experimental mill, in which all processes involved in the production of woollen and worsted cloth, from the raw material to the finished articie, can be carried out on a practical scale. The building comprises a three-storey front block I75 feet long, devoted to lecture-rooms, textile testing-room, museum, experimental rooms, \&c. Behind this are two large sheds, each 90 feet by 70 feet, one containing the combing, carding, and spinning machinery, and the other the looms. The equipment for the production of yarns of various types is very complete, consisting of Preparing Box, Worsted Carding Engine, Noble Comb, French NO. 2 I92, VOL. 88$]$
Comb, French, Cone, and Open Drawing Sets, Flyer, Cap and Ring Spinning Frames. In a separate shed are warping mills and dressing frames, while the power looms include examples of all types. The wool-washing room contains three bowls of a total length of about 80 feet. The practical dyehouse and finishing rooms each have an area of about 300 square yards, and are equipped with fullsize machines for the treatment of loose wool, slubbing, yarns, and piece goods.

A detached building houses the power plant, which includes a 30 foot by 8 foot boiler, with superheater, economiser, \&c. The engine-house contains four prime movers, a suction gas engine of 125 horse-power, a slowspeed cross-compound engine of 200 horse-power, a highspeed inverted vertical engine of 75 horse-power, and a steam turbine of about the same power. Each of the three engines drives a direct-current generator, while the turbine is coupled to a three-phase alternator. Both engine- and boiler-houses are fitted with a complete set of testing apparatus; but while primarily intended for educational work, the power plant will provide light and electrically transmitted power for three large buildings-the main college block, the extension, and the school of art.

The new buildings have been erected at the cost of about $20,000 l$., and for the equipment an additional sum of about I $4,000 l$. has been provided, which sum would have been much increased but for the generosity of most of the machine makers, who have supplied the equipment on very favourable terms. Much of the machinery throughout the building has been specially designed, so that while of a thoroughly practical character, experimental work not possible in a mill can be carried out.

\section{ZOOLOGY AT THE BRITISH ASSOCIATION.}

\section{SECTION D presented a full and varied programme,} and the attendance at the several sessions was above the average of recent meetings. This meeting was undoubtedly one of the best of recent years.

As in previous years, there were two lectures of a semipopular character, which were highly appreciated. $\mathrm{Mr}$ Fred Enock lectured on the "fairy flies" (Mymaridæ), hymenopterous insects of small size and with peculiar delicate wings, without veins, but fringed with long hairs. Mr. Enock, who has devoted many years to the study of this family, illustrated his account by means of a beautiful series of original drawings, shown by the lantern. $\mathrm{He}$ described the principal characters of the male and female, and traced the life-history of Anagrus incarnatus, the eggs of which are laid in the egg of the frog-hopper.

In his lecture on the fossil reptiles of the Oxford Clay of Peterborough, Dr. C. W. Andrews gave an account of the remarkable assemblage of reptiles occurring in that deposit. The beds in which the remains were found are of Middle Jurassic age, and were probably laid down not far from land and near the mouth of a large river. The horizon at which the remains occur is that characterised by ammonites of the "ornate" group, Cosmoceras gulielmi being a common species. Among the remains are those of land reptiles carried down by the river and of many marine forms of several distinct orders. Cetiosaurus, a terrestrial dinosaur allied to Diplodocus, attained a length of 60 feet, the greater part being made up of the greatly elongated neck and tail. Another, but smaller, dinosaur, Stegosaurus, and a pterodactyl, Rhamphorhynchus, were also found. The marine reptiles were more numerous, and of astonishing variety of form; for instance, ichthyosaurs, plesiosaurs of many types, and numerous marine crocodiles of the genera Metriorhynchus and Stenosaurus. The ichthyosaur Ophthalmosaurus was remarkable for the fact that in the adult the teeth were extremely small, and in some cases perhaps absent, so that the food of this animal must have been very different from that of its relatives. In many cases the skeletons were found in a nearly complete condition; in others the carcases seem to have been torn to pieces by predaceous reptiles, the bones being deeply scored by their teeth. Dr. Andrews exhibited a series of lantern-slides showing the actual remains and reconstructions based upon these. $\mathrm{He}$ stated that the

1 "Some Recent Work on Sex" and an acconnt of the discussion on the origin of mammals will form the subject of separate no:ices. 